\title{
Relationships between aromatase activity, follicular fluid oestradiol-17 $\beta$ and testosterone concentrations, and diameter and atresia of individual ovine follicles
}

\author{
C. G. Tsonis*, R. S. Carson and J. K. Findlay \\ Medical Research Centre, Prince Henry's Hospital, Melbourne, Victoria 3004, Australia
}

\begin{abstract}
Summary. Aromatase activity was measured in granulosa cells using a $1-\mathrm{h}$ in-vitro assay. This activity correlated with the concentration of oestradiol-17 $\beta$ and the ratio of oestradiol-17 $\beta$ to testosterone in follicular fluid of individual follicles ranging from 1.5 to $7.0 \mathrm{~mm}$ diameter. These data show an 8-10-fold difference in aromatase activity between small and large follicles and that aromatase activity per cell increased in small non-atretic follicles $(<3.5 \mathrm{~mm})$ whereas it remained relatively constant in large nonatretic follicles $(\geqslant 3.5 \mathrm{~mm}$ ). Aromatase activity was much lower in follicles at more advanced stages of atresia. Atresia was assessed using the morphological and the morphometric methods ( $\%$ of maximum number of granulosa cells/follicle). Although the morphological method of assessment was preferable to the morphometric method, it did not differentiate a decrease in aromatase activity as a very early event in the atretic process. We believe this is due to the inability of these methods to detect follicles in the initial stages of atresia.
\end{abstract}

\section{Introduction}

It is known that antral follicular development is dependent upon intrafollicular oestrogen (Richards et al., 1976; Richards \& Kersey, 1979) and that increased aromatization of androgens to oestrogens by granulosa cells is the hallmark of an ovulatory follicle (McNatty, Moore-Smith, Makris, Osathanondh \& Ryan, 1979). Conversely, measurements of oestrogen production by follicles (Moor, Hay, Dott \& Cran, 1978) and granulosa cells in vitro (Moor, 1977; McNatty, 1981) indicate that reduced aromatase activity in granulosa cells is associated with atresia. Moor et al. (1978) and Carson, Findlay, Clarke \& Burger (1981) concluded that reduced aromatase activity in atretic antral follicles of sheep was due to a loss of existing aromatase activity rather than a failure to acquire this activity initially, and suggested that a decrease in the aromatase activity was an early event in the atretic degeneration of antral follicles.

Measurement of aromatase activity has involved culture of ovine follicles or granulosa cells for 24-48 h (Moor, 1977; Moor et al., 1978; McNatty, 1982), conditions which are known to be suboptimal for aromatase activity (Moor, 1977). Therefore, aromatase activity of granulosa cells found with these methods may not be a true reflection of the changes that occur during growth and atresia in vivo.

The present study was undertaken, using a rapid assay for aromatase activity in granulosa cells, to determine (a) whether reduced aromatase activity is an early event in the atresia of ovine follicles, and (b) the relationship which may exist between aromatase activity and follicular growth.

\footnotetext{
* Present address : Department of Obstetrics and Gynaecology, University of Edinburgh, Centre for Reproductive Biology, 37 Chalmers Street, Edinburgh EH3 9EW, U.K.
} 
The opportunity was taken to make a direct comparison of two published methods for assessing atresia in individual ovine follicles. Part of this work has been published in abstract form (Tsonis \& Findlay, 1981).

\section{Materials and Methods}

\section{Isolation of follicles}

Ovaries were obtained predominantly from Merino and Merino-cross ewes slaughtered commercially at unspecified times of the luteal phase of the oestrous cycle. Ovaries were placed in $0.154 \mathrm{M}-\mathrm{NaCl}$ (saline) containing $50 \mathrm{U}$ kanamycin (Sigma, Melbourne, Australia) $/ \mathrm{ml}$ and 0.1\% (w/v) glucose (BDH Chemicals, Melbourne, Australia) and transported on ice to the laboratory within $1-2 \mathrm{~h}$ of slaughter. Individual follicles $(\mathbf{N}=221)$ were dissected and the diameter of each measured to the nearest $0.1 \mathrm{~mm}$ using a stereo-microscope fitted with an ocular graticule. The mean of two perpendicular diameters was used. Volume of fluid (V) contained within each follicle was calculated using follicular diameter (D) and the formula, $\mathrm{V}=0.52(\mathrm{D})^{2 \cdot 7}$ (Carson et al., 1981).

\section{Methods of assessing atresia}

Morphological assessment. The stage of atresia was assessed by morphological criteria (Moor et al., 1978; Carson, Findlay, Burger \& Trounson, 1979), and graded I-V, in order of increasing atresia. The criteria used were: (a) continuity of the membrana granulosa, (b) presence or absence of the oocyte-cumulus complex, and (c) the degree of thecal vascularization.

Morphometric assessment. The number of granulosa cells present in any follicle was expressed as a percentage of the maximum number of granulosa cells observed in follicles of the same diameter, indicated by the line in Text-fig. 1(a). Follicles were assigned to one of four classes $(>75 \%, 75-51 \%$, $50-26 \%, 25-0 \%$; in order of increasing atresia) in which follicles with $\geqslant 50 \%$ granulosa cell number were considered non-atretic and follicles with $<50 \%$ granulosa cell number were considered atretic (McNatty, 1981, 1982).

\section{Isolation of follicular fluid, theca and granulosa cells}

Each follicle was hemisected in a known volume of Medium 199 buffered with 20 mM-Hepes ( $N$-2-hydroxyethylpiperazine- $N$-2-ethanesulphonic acid; CSL, Melbourne, Australia) containing $50 \mathrm{U}$ kanamycin $/ \mathrm{ml}$, and the resultant suspension centrifuged $(800 \mathrm{~g})$ for 5-10 $\mathrm{min}$ at room temperature. The supernatant was harvested and stored frozen at $-15^{\circ} \mathrm{C}$ until assayed for oestradiol-17 $\beta$ and testosterone.

Pellets of theca and granulosa cells were resuspended in $500 \mu \mathrm{l}$ of the medium, containing $1.7 \mathrm{~mm}$ EGTA (Sigma, Melbourne, Australia) and incubated for 10-15 min at room temperature. Granulosa cells were removed by scraping the everted follicle wall with fine forceps. The follicle wall (essentially devoid of granulosa cells and hereafter referred to as the theca) was blotted to remove excess medium and weighed.

Media containing the granulosa cells were aspirated several times with a flame-polished, siliconized Pasteur pipette before transferring to a tube which contained 1-2 ml Medium 199. After aspirating again to wash the cells, the suspension was centrifuged as above. The supernatant was discarded and the pellet was resuspended in a known volume of Medium 199. An aliquant of the cells was counted using a haemocytometer. Cell viability was determined after vital staining with $0.4 \%$ trypan blue and was in the range of $30-60 \%$. By using viable cell number to calculate aromatase activity per cell we may be overestimating the activity if cells which take up dye are still active. However, the extent to which this occurs is not known. 
Replicate aliquants of $100 \mu \mathrm{l}$ of each suspension of granulosa cells were transferred to glass scintillation vials, containing $10^{-7} \mathrm{M}$-testosterone in Medium 199 and fetal calf serum $(2 \cdot 5 \% \mathrm{v} / \mathrm{v}$; CSL, Melbourne, Australia) and $50 \mathrm{U}$ kanamycin $/ \mathrm{ml}$ to a final volume of $1 \mathrm{ml}$. Cell samples were incubated in triplicate for $1 \mathrm{~h}$ at $37^{\circ} \mathrm{C}$ under an atmosphere of $95 \%$ air:5\% $\mathrm{CO}_{2}$ in an oscillating water bath $(120$ cycles $/ \mathrm{min})$. The assay was terminated by placing each vial on ice for $5 \mathrm{~min}$ before centrifugation at $800 \mathrm{~g}$ for $10 \mathrm{~min}$ at room temperature. Individual supernatants were stored at $-15^{\circ} \mathrm{C}$ until assayed for oestradiol-17 $\beta$. The optimization of this assay included studies of the effect of cell number, duration of incubation, and substrate concentration (see 'Results'; Text-fig. 2).

The oestradiol- $17 \beta$ concentration in medium containing cells at zero time was subtracted as a blank. Aromatase activity was expressed as ng oestradiol- $17 \beta / 10^{6}$ viable cells $/ \mathrm{h}$.

\section{Steroid radioimmunoassays}

Oestradiol-17 $7 \beta$ concentrations were determined using reagents and either radioiodinated or tritiated oestradiol-1 $7 \beta$ provided by WHO, Geneva, Switzerland. All samples were extracted with diethyl ether before assay at several dilutions. Using the iodinated trace ( ${ }^{125}$ I-labelled oestradiol$17 \beta ; 10000$ c.p.m./tube), the assay was specific for oestradiol-17 $\beta$, with only minor cross-reaction with other steroids (oestradiol- $17 \alpha, 0.04 \%$; oestrone, $0.2 \%$. Sensitivity of this assay was $0.01 \mathrm{pg} /$ tube and assay blanks were always less than this value. Intra-assay coefficients of variation (CV) for 33 consecutive assays were $<15 \%$ over the range $0.4-23.4 \mathrm{pg} /$ tube (minimum $8.2 \%$ ) and the interassay CV was $10 \cdot 7 \%$.

When $\left[{ }^{3} \mathrm{H}\right.$ ]oestradiol-17 $\beta$ was used as trace, (sp. act. $85 \mathrm{Ci} / \mathrm{mmol}$ ) in conjunction with a antiserum different from that used with ${ }^{125} \mathrm{I}$-labelled oestradiol the assay was specific for oestradiol- $17 \beta$, with only minor cross-reaction with other steroids (oestriol, $0.3 \%$; oestrone, $1-2 \%$ ). Sensitivity of this assay was $3.21 \mathrm{pg} /$ tube and assay blanks were always less than this value. The intra-assay CV for 12 consecutive assays was $<15 \%$ over the range $12 \cdot 0-488.0 \mathrm{pg} /$ tube (minimum $7.2 \%$ ) and the interassay CV was $10.9 \%$. Five samples of media measured in both oestradiol assay systems had similar values $(r=0.998)$.

Testosterone concentrations were determined after extraction of 5-20 $\mu$ l diluted follicular fluid with $1 \mathrm{ml}$ diethyl ether. The extracted and unextracted follicular fluid diluted parallel to the standard curve. The antiserum was specific for testosterone with only minor cross-reaction with other steroids (oestradiol-17, $0.04 \%$, androstenedione, $0.04 \% ; 5 \alpha$-dihydrotestosterone, $7.8 \%$ ). Sensitivity of this assay was $8.6 \mathrm{fg} /$ tube and assay blanks were always less than this value. The intraassay $\mathrm{CV}$ for 3 consecutive assays was $<15 \%$ over the range $35-5488 \mathrm{fg} /$ tube (minimum $6.1 \%$ ) and the inter-assay $\mathrm{CV}$ was $5 \cdot 8 \%$.

Corrections for procedural losses were not made in any of the above assays because the extraction efficiency, measured the same way, was in the range of 90-95\%. All radioimmunoassay data were processed using the computer program described by Burger, Lee \& Rennie (1972).

\section{Statistical analysis}

Follicles were divided into small $(<3.5 \mathrm{~mm})$ and large $(\geqslant 3.5 \mathrm{~mm})$ groups, based on the knowledge that at a diameter of $\sim 3.5 \mathrm{~mm}$ sheep follicles undergo significant changes in steroidogenic capacity and LH receptor number (Carson et al., 1979, 1981). Data were transformed into natural logarithms and analysed using an unpaired $t$ test and with ANOVA and Duncan's multiple range analysis. Correlations were performed on transformed data using linear and family (curvilinear) regressions (Sokal \& Rohlf, 1981). 


\section{Results}

Follicular diameter, thecal wet weight, fluid volume and granulosa cell number

The maximum number of granulosa cells present in follicles of a given diameter was best described by the logarithmic function: $y=\mathrm{A}+\mathrm{B} \ln x$, where $y=$ the number of granulosa cells, $x=$ follicular diameter in $\mathrm{mm}(x \geqslant 1) ; \mathrm{A}=206612 ; \mathrm{B}=3229327 ; r=0.994(\mathrm{~N}=221)$, $P<0.001$, and is shown by the line in Text-fig. 1(a).

Because the relationship between thecal wet weight and follicular diameter was not influenced by atresia (data not shown), the data on thecal weight of all follicles were combined and the relationship to follicular diameter is described by the equation; $y=0.212 x^{1.82}, r=0.902(\mathrm{~N}=$ 211), $P<0.001$ (Text-fig. 1b). For comparison, follicular fluid volume, described by the equation $\mathrm{V}=0.52 \mathrm{D}^{2 \cdot 7}$ (Carson et al., 1981), is also shown in Text-fig. 1(b).



Text-fig. 1. Relationships between granulosa cell number (a) and thecal wet weight and volume of follicular fluid (b) and follicular diameter. In (a) $y=206612+3229327 \ln x(x \geqslant 1)$, $r=0.994, \mathrm{~N}=221, P<0.001$. In (b) $y=0.212 x^{1.82}, r=0.902, \mathrm{~N}=211, P<0.001$ for thecal wet weight and $\mathrm{V}=0.52 \mathrm{D}^{2 \cdot 7}$ for follicular fluid volume.

\section{Validation of aromatase assay}

Optimal assay conditions were established by studies of the time course of oestrogen production (Text-fig. 2a), and the effects of cell number (Text-fig. 2b) and concentration of exogenous testosterone substrate (Text-fig. 2c). Based on these data, granulosa cells were assayed at concentrations up to $3 \times 10^{5}$ viable cells/vial which gave a linear reaction rate during a $1-\mathrm{h}$ incubation at $37^{\circ} \mathrm{C}$ in the presence of $10^{-7} \mathrm{M}$-testosterone.

\section{Aromatase activity and oestradiol-17\% and testosterone in follicular fluid}

Positive correlations were evident between aromatase activity $(x)$ and follicular fluid concentrations of oestradiol-17 $\beta(y)$ of small $\left(\mathrm{N}=31, r=0.686, \mathrm{~F}_{1,29}=24.02, P<0.001, \ln y=\right.$ $0.893 \ln x+2.073)$ and large follicles $\left(\mathrm{N}=58, r=0.792, \mathrm{~F}_{1,56}=94.5, P<0.001, \ln y=0.705 \ln x\right.$ +2.982 ) (data not shown).

A positive correlation was also observed between aromatase activity $(x)$ and the ratio of oestradiol-17 $\beta$ to testosterone concentrations $(y)$ in follicular fluid of small $(r=0.747, \mathrm{~N}=14$, 

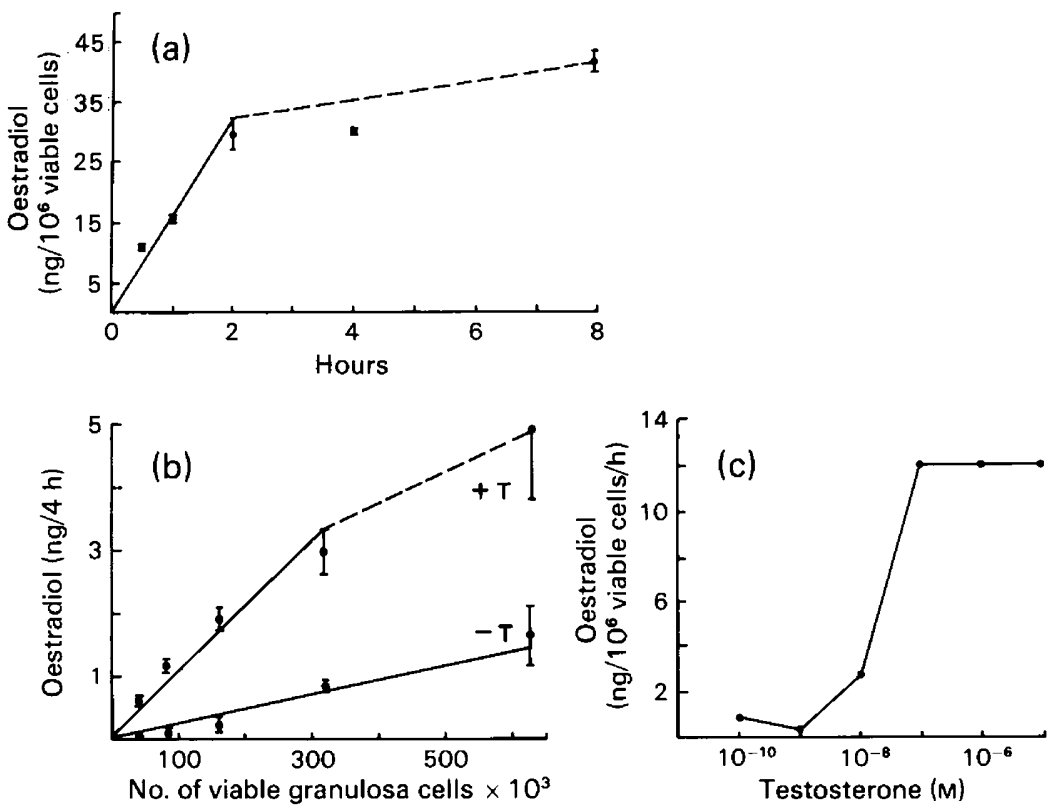

Text-fig. 2. Assay conditions for aromatase activity in granulosa cells: (a) time course, with $10^{-7} \mathrm{M}$-testosterone substrate and $85 \times 10^{3}$ viable cells, (b) cell number with and without $10^{-7}$ $M$ testosterone ( $T$ ) substrate, and (c) concentration of exogenous testosterone substrate with 135 $\times 10^{3}$ viable cells for $1 \mathrm{~h}$.

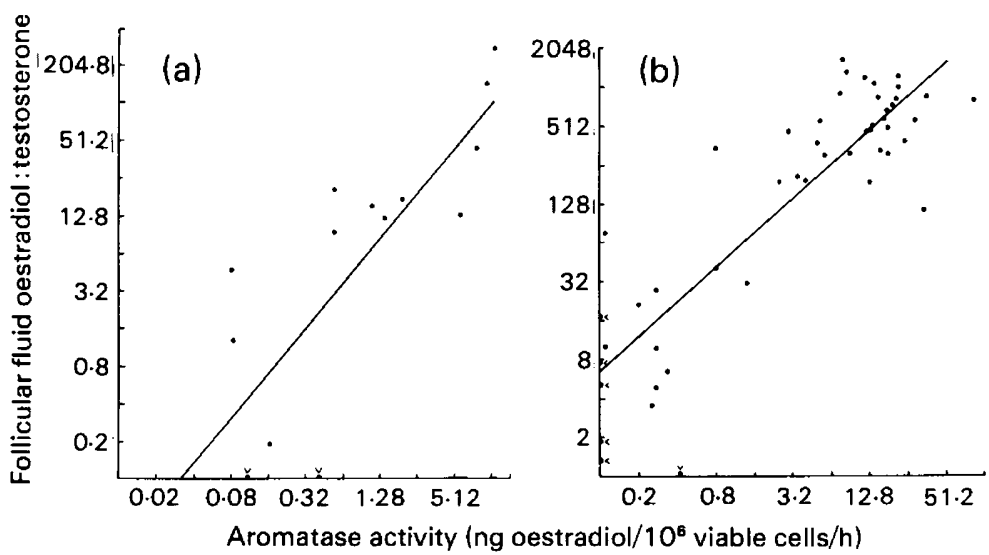

Text-fig. 3. Relationship between the ratio of oestradiol-17 7 to testosterone concentrations in follicular fluid and aromatase activity in granulosa cells of (a) small $(<3.5 \mathrm{~mm})$ and (b) large $(\geqslant 3.5 \mathrm{~mm}$ ) follicles. In (a) $\ln y=1.20 \ln x+1.81, r=0.747, \mathrm{~N}=14, P<0.001$. In (b), $\ln y=$ $0.888 \ln x+3.91, r=0.836, \mathrm{~N}=49, P<0.001$.

$F_{1,12}=15.1, P<0.001, \ln y=1.20 \ln x+1.81 ;$ Text-fig. 3a) and large follicles $(r=0.836, \mathrm{~N}=$ $49, \mathrm{~F}_{1,47}=108.6 ; P<0.001, \ln y=0.888 \ln x+3.91$; Text-fig. 3b).

\section{Aromatase activity and atresia}

Small follicles. Aromatase activity was significantly decreased in advanced morphological atresia (stage V) compared with siages I, II, and III $\left(\mathrm{F}_{4,26}=2.701 ; P<0.05\right)$, but not between stages I and IV (Text-fig. 4a). The overall correlation between the aromatase activity $(\dot{y})$ and the 5 
stages of morphological atresia $(x)$ was not significant $(r=-0.3199)$. In contrast, a positive correlation was observed between the aromatase activity $(y)$ and atresia assessed by the $\%$ granulosa cell number $(x)(r=0.40, P<0.05, \ln y=0.927 x-1.641)$. Significant differences in aromatase were observed between stages $75-51 \%$ and $25-0 \%$ and between $75-51 \%$ and $50-26 \%$ $\left(\mathrm{F}_{2.28}=3.201 ; P<0.05\right.$; Text-fig. 4b). No follicles $<3.5 \mathrm{~mm}$ had greater than $75 \%$ of their maximal granulosa cell number in which aromatase activity was determined.

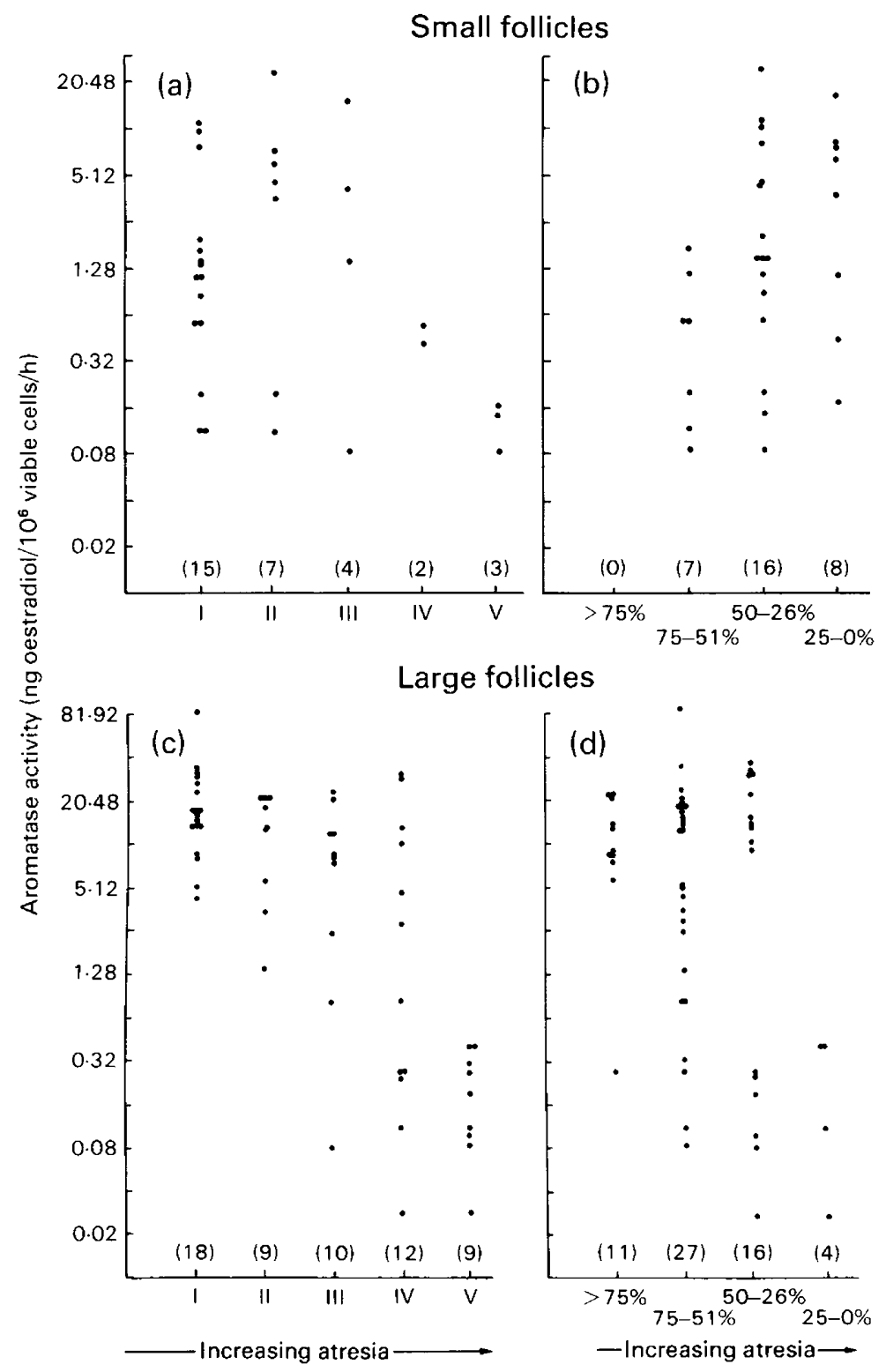

Text-fig. 4. Relationship between aromatase activity in granulosa cells and atresia in (a, b) small ( $<3.5 \mathrm{~mm}$ ) and $(\mathrm{c}, \mathrm{d})$ large $(\geqslant 3.5 \mathrm{~mm})$ follicles, assessed using (a, c) morphological and (b, d) morphometric methods. For small follicles, in (a) $r=-0.3199, \mathrm{~N}=31$, N.S., and in (b) $\ln y=0.927 x-1.641, r=0.40, \mathrm{~N}=31, P<0.05$. For large follicles, in (c) $\ln y=-1.05 x+$ $4 \cdot 18, r=-0.73, \mathrm{~N}=58, P<0.001$, and in (d) $\ln y=-0.966 x+3.45, r=-0.38, \mathrm{~N}=58$, $P<0.01$. 
Large follicles. There was a negative correlation between the aromatase activity $(y)$ and the 5 stages of morphological atresia $(x)(r=-0.73 ; P<0.001, \ln y=-1.05 x+4.18)$. There were significant differences between the various stages of morphological atresia and the aromatase activity; stage I versus III $(P<0.05)$, stage I versus IV and V, II versus IV and V, III versus V, and IV versus $\mathrm{V}\left(\mathrm{F}_{4,53}=17.8, P<0.01\right.$; Text-fig. $\left.4 \mathrm{c}\right)$ but not for stage I versus II or II versus III. A negative correlation was also observed between the aromatase activity $(y)$ and the $\%$ granulosa number $(x)(r=-0.38 ; \mathrm{N}=58, P<0.01, \ln y=-0.966 x+3.45)$. Using this morphometric method of classifying atresia, the aromatase activity was only significantly lower in the $25-0 \%$ group $\left(\mathrm{F}_{3.54}=4.41, \mathrm{~N}=58, P<0.01\right.$; Text-fig. $\left.4 \mathrm{~d}\right)$ compared to all other groups.

\section{Aromatase activity and follicular growth}

Aromatase activity in relation to follicular growth, represented by follicular diameter at all stages of morphological atresia, is shown in Text-fig. 5. It was assumed that stages I and II represent essentially non-atretic follicles on the basis of high aromatase activity (Text-fig. 4) and limited differences in gonadotrophin receptor number and steroid content (Carson et al., 1979, 1981). In small follicles $(<3.5 \mathrm{~mm})$ in stages I and II, there was a positive correlation between aromatase activity and follicular diameter indicating that the aromatase activity $(y)$, on a per cell basis, increased with increasing follicular diameter $(x)(1 \leqslant x<3.5 \mathrm{~mm} ; r=0.623, P<0.001$, $\ln y$ $=1.702 x-3.455$ ). Small follicles in more advanced stages of atresia had aromatase activity in the granulosa cells which fell below this line, with one exception (Text-fig. 5a).

In large follicles ( $\geqslant 3.5$ but $<8 \mathrm{~mm}$ ) at stages I and II, aromatase activity $(y)$ did not change significantly with follicular diameter $(x)(r=0 \cdot 019)$. Aromatase activity in large follicles in more advanced stages of atresia were generally below this line, especially follicles of stage $\mathrm{V}$ of atresia (Text-fig. 5b).

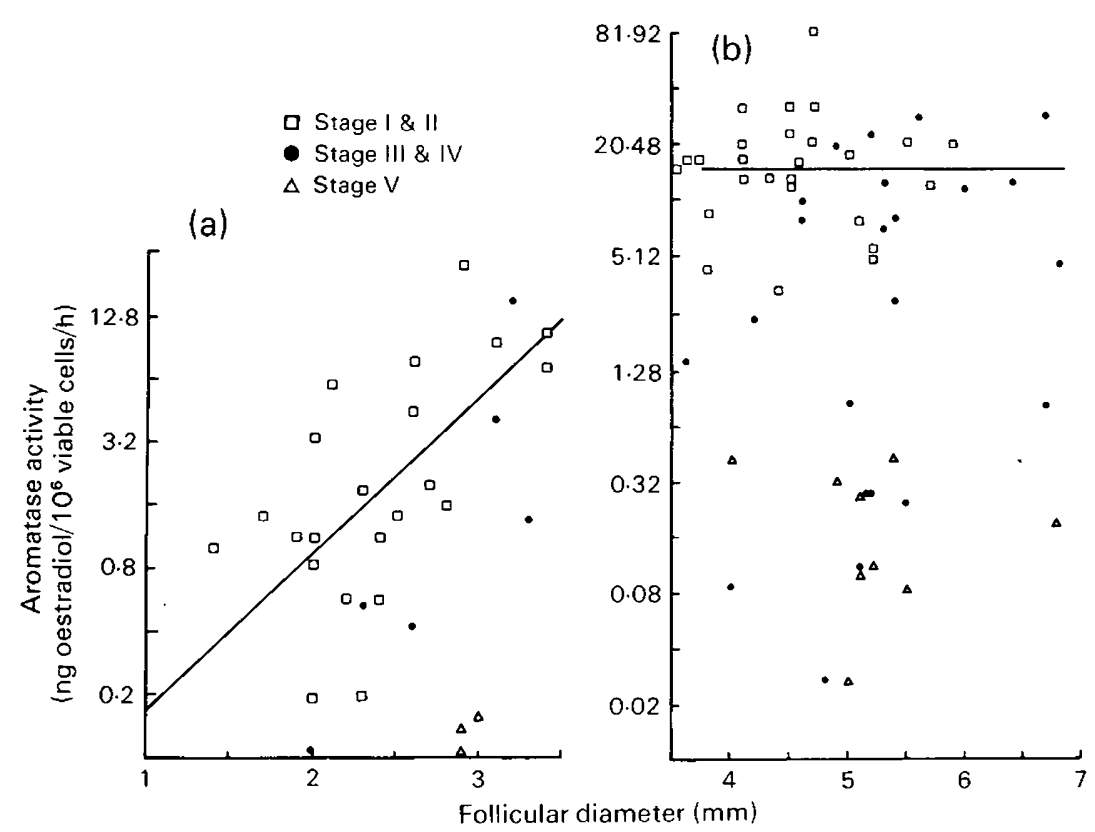

Text-fig. 5. Relationship between aromatase activity in granulosa cells and follicular diameter of (a) small $(<3.5 \mathrm{~mm})$ and (b) large $(\geqslant 3.5 \mathrm{~mm})$ follicles at various stages of atresia assessed morphologically. The lines represent the relationships between aromatase activity and diameter of follicles in stages I and II (non-atretic) only: In (a) $\ln y=1.702 x-3.455, r=$ $0.623, \mathrm{~N}=22(1 \leqslant x<3.5 \mathrm{~mm}), P<0.001$, and in (b) $\ln y=0.021 x+2.648, r=0.019, \mathrm{~N}=$ $26(3 \cdot 5 \leqslant x<8 \mathrm{~mm})$, N.S. 


\section{Comparison of the morphological and morphometric methods of assessing atresia}

A comparison was made between the two methods of classifying atresia in 31 small and 58 large follicles (Text-fig. 6a, b). In small follicles the morphometric method indicated that $7 / 31$ follicles were considered healthy $(\geqslant 50 \%)$ whereas the morphological method of assessment indicated that $22 / 31$ follicles were healthy (stages I and II). In the large follicles, however, the situation was reversed. The morphometric method indicated that $38 / 58$ large follicles were considered healthy while the morphological method suggested that $27 / 58$ follicles were healthy. These data show that the morphological method assesses more healthy small follicles, but fewer healthy large follicles, while the morphometric method shows the reverse.

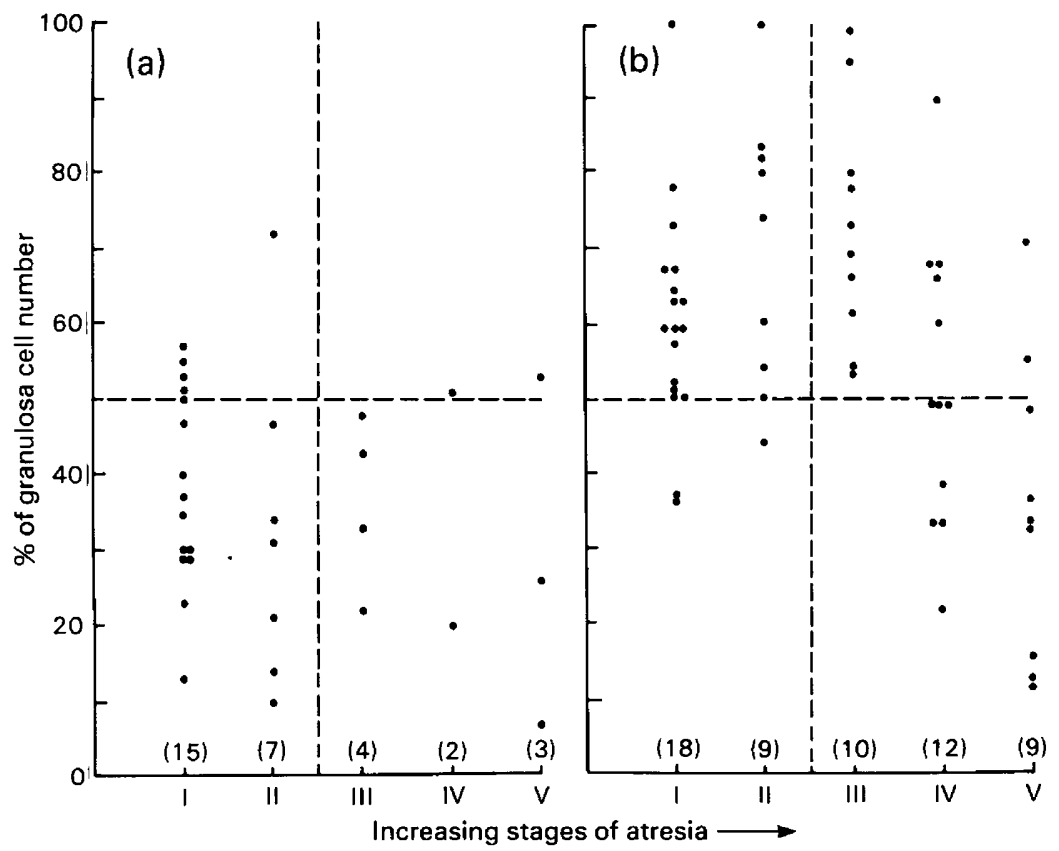

Text-fig. 6. A comparison between the morphological and morphometric methods of assessing atresia in (a) small $(<3.5 \mathrm{~mm})(\mathrm{N}=31)$ and (b) large $(\geqslant 3.5 \mathrm{~mm})(\mathrm{N}=58)$ follicles. The broken lines distinguish the non-atretic and atretic follicles as defined by each method.

The 3 large follicles in stages I and II which had $<50 \%$ of maximal granulosa cell number had relatively high ( $15-31 \mathrm{ng}$ oestradiol $-17 \beta / 10^{6}$ viable cells $/ \mathrm{h}$ ) aromatase activity whereas the 7 follicles in stages IV and $\mathrm{V}$ with $>50 \%$ of maximal granulosa cell number had low aromatase activity $(0 \cdot 1-5$ ng oestradiol- $17 \beta / 10^{6}$ viable cells/h) (Text-fig. $\left.6 \mathrm{~b}\right)$ compared with the mean aromatase activity of all follicles in stages I and II of morphological atresia $\left(14 \cdot 2(10 \cdot 8-18 \cdot 7) \mathrm{ng}\right.$ oestradiol-17 $\beta / 10^{6}$ viable cells $/ \mathrm{h}$; mean $\pm 95 \%$ confidence interval) (see Text-fig. $5 \mathrm{~b}$ ).

\section{Discussion}

Our data show there is an 8-10-fold difference in aromatase activity between small and large follicles and that aromatase activity per cell increases in small non-atretic follicles $(<3.5 \mathrm{~mm})$, whereas it remains relatively constant in large non-atretic follicles ( $\geqslant 3.5 \mathrm{~mm}$ ). Aromatase activity was much lower in follicles at more advanced stages of atresia. Whereas maximal numbers of granulosa cells present in the largest sheep follicles $(6-7 \mathrm{~mm})\left(5-6 \times 10^{6}\right.$ cells/follicle; Text-fig. 1a) 
were comparable to values obtained by L. P. Cahill (unpublished observations) using histological techniques, these values differ from those reported by others. McNatty (1982), using Romney ewes, found 8-9 $\times 10^{6}$ granulosa cells, while Baird, Ralph, Seamark, Amato \& Bindon (1982) found that Booroola Merino and Merino ewes had $0.6 \times 10^{6}$ and $1.5 \times 10^{6}$ cells/follicle respectively. These differences in number of granulosa cells/follicle could be due to a breed difference or technical differences in harvesting and counting the cells. Actively growing sheep follicles are characterized by an exponential increase in thecal wet weight (Text-fig. 1b). These appear to be the only data relating thecal wet weight to follicle diameter in sheep, although Weiss, Seamark, McIntosh \& Moor (1976) developed formulae, derived experimentally, to determine the wet weights of various follicular components. McNatty (1981) has shown a similar relationship between thecal wet weight and growth of the human follicle, both of which parallel increases in antral fluid volume as indicated for the sheep (Text-fig. 1b).

There is evidence that aromatase activity of granulosa cells in culture is lost after a few hours (Moor, 1977; Hay \& Moor, 1978; McNatty et al., 1984). Although follicles can show morphological regeneration in culture, they still lack aromatase activity (Hay \& Moor, 1975, 1978; Hay, Moor, Cran \& Dott, 1979). For these reasons we believe that the conditions used to measure aromatase activity in the above-mentioned studies were suboptimal. A rapid aromatase assay was developed which might reflect more accurately the in-vivo rate of activity in granulosa cells. Since the development of this short assay, Hillier, Reichert \& van Hall (1981) described a 3-h aromatase assay for human granulosa cells and McNatty et al. (1984) have described a 3-h assay system for granulosa cells of the sheep. If the aromatase activity measured in our short assay is a true measure of the activity in vivo one would expect the positive relationship between aromatase activity and the follicular oestradiol-17 $\beta$ concentration in both small and large follicles. Aromatase activity was also strongly correlated with the ratio of oestrogen to androgen, an index of follicular atresia whereby the lower the ratio the more atretic the follicle (McNatty et al., 1979; Carson et al., 1981; Hillier et al., 1981). This underlines the fact that in atresia of sheep follicles it is the lack of aromatase and not androgen substrate which limits oestrogen production.

Aromatase activity was related to follicular growth in small follicles. This increase in aromatase activity per cell has also been observed by McNatty (1982) using sheep granulosa cells cultured for $48 \mathrm{~h}$ with and without FSH. McNatty (1982) found that healthy antral follicles $(0.5-4 \mathrm{~mm})$ stimulable with FSH had an increase in aromatase activity per cell as follicles increased in diameter up to $4 \mathrm{~mm}$. Beyond this diameter the FSH-stimulable aromatase activity was not different from the basal levels, although aromatase activity continued to increase with increasing diameter. Moor (1977) reported that aromatase activity in granulosa cells from follicles of $3.5-4.5 \mathrm{~mm}$ diameter can be stimulated by FSH when cultured for $48 \mathrm{~h}$. Moreover, he showed that FSH-primed cells displayed a higher level of aromatase activity than did unstimulated cells even after $72 \mathrm{~h}$ of culture. However, there was a rapid decline in aromatase activity in control and FSH-primed cells after 24 $\mathrm{h}$. We did not observe a significant increase in the aromatase activity per cell in follicles $\geqslant 3.5 \mathrm{~mm}$ even after FSH stimulation for up to $48 \mathrm{~h}$ culture (C. G. Tsonis, unpublished observations). Because the data of McNatty (1982) are based on 48-h cultures of granulosa cells, his observations may be indicative of the capacity of cells and aromatase activity to survive in culture rather than a true reflection of in-vivo cellular aromatase which we believe is measured in a $1-3-\mathrm{h}$ assay. Our data suggest that in small antral follicles increasing oestradiol-17 $\beta$ biosynthesis reflects increasing aromatase activity per cell (in part), whereas in large follicles it probably mainly reflects increasing cell number.

In small follicles aromatase activity was not strongly correlated with atresia when assessed by either method. The two methods appeared contradictory in that there were significant decreases in aromatase activity in advanced morphological atresia (stage V) and stages I, II and III, but not between I to IV; while with the \% granulosa number method there was an apparent increase in aromatase activity with increasing atresia in these small follicles. However, no follicles having $>75 \%$ of their granulosa cell number were included and this would have biased the relationship. In 
large follicles there was an inverse relationship between aromatase activity and stage of atresia; that is, large follicles contained lower aromatase activity at the more advanced stages of atresia. The morphological method of assessing atresia was preferable for large follicles for the following reasons: (a) there was a much stronger correlation between aromatase activity and stage of atresia, (b) fewer large healthy follicles were distinguished, which would be expected from histological evidence (Cahill, 1979), and (c) several of the follicles which were considered healthy morphometrically but atretic morphologically had very low aromatase activity, suggesting that these follicles were, in fact, atretic. Other evidence suggests that morphological criteria do provide a reliable assessment of the true functional state of any follicle particularly at each end of the atresia spectrum (Moor et al., 1978; Carson et al., 1981; Kruip \& Dieleman, 1982). However, we were not able to demonstrate any difference in aromatase activity between stages I and II of morphological atresia in small or large follicles.

We believe there are limitations inherent with both methods of assessing atresia. Firstly both methods of classification are less reliable for small follicles. In small follicles there are logarithmic increases in granulosa cell number (Text-fig. 1a) and aromatase activity (Text-fig. 5a) with increasing follicle diameter; because of these changes it may be difficult to resolve early changes in atresia reflected by a fall in aromatase activity. In large follicles the increase in granulosa cell number is not as dramatic, while the aromatase activity does not change significantly on a per cell basis with increasing diameter, so a decrease in aromatase activity in early atresia would be more obvious. A second limitation may be in using follicles chosen from ovaries at random stages of the luteal phase of the oestrous cycle in that it may be more difficult to detect subtle changes in aromatase activity with atresia, assessed by morphological or morphometric criteria. A better approach might be to use ovaries at a specific stage of the cycle using the models developed by Tsonis, Cahill, Carson \& Findlay (1984) and Driancourt \& Cahill (1984) to identify groups of follicles at known stages of development and to determine the relationship between aromatase activity and atresia. Thirdly, problems may exist with the sensitivity of these methods of assessing atresia, in particular determining the 'initial' stages of atresia. One of the reasons for not being able to detect a decrease in aromatase activity with very early stages of atresia may be related to the fact that it may occur within hours of the follicle entering the atretic process whereas the morphological and/or morphometric changes may take days to become apparent. Alternatively, a decrease in aromatase activity may not be an early event in atresia. Often there is also a problem of distinguishing follicles in stages III and IV of morphological atresia, so it may be better to use the three classes originally described by Moor et al. (1978).

Histology of individual follicles was not correlated with aromatase activity in this study mainly because it was not possible to do histology and obtain information on the number of granulosa cells per follicle. Also, there is evidence to suggest that normal healthy follicles can have up to 5 pycnotic nuclei in membrana granulosa of sheep, horse and monkeys (Hay, Cran \& Moor, 1976; Driancourt, Mariana \& Palmer, 1981 ; Koering, Goodman, Williams \& Hodgen, 1982), throwing some doubt on the validity of this criterion used to assess atresia histologically.

In conclusion the present data indicate that aromatase activity on a per cell basis increased in growing follicles up to $3.5 \mathrm{~mm}$ diameter and thereafter remained relatively constant, whereas it decreased in atretic follicles. The morphological method of assessment of atresia seemed preferable to the morphometric method, but it did not reveal a decrease in aromatase activity as a very early event in the atretic process. We believe that this is due to limitations of the methods for assessing atresia.

We thank Dr K. Ouch and Dr R. I. Cox for testosterone trace and antiserum; WHO for radioimmunoassay reagents and standards; Julie Coleman for secretarial assistance; and Anne Saunders for help in preparation of the figures. C.G.T. is a postgraduate scholar of the Australian Meat Research Committee and this project was supported by the Australian Meat Research Committee and National Health and Medical Research Council of Australia. 


\section{References}

Baird, D.T., Ralph, M.M., Seamark, R.F., Amato, F. \& Bindon, B.M. (1982) Pre-ovulatory follicular activity and estrogen secretion of high (Booroola) and low fecundity Merino ewes. Proc. Aust. Soc. Reprod. Biol. 14, Abstr. 83.

Burger, H.G., Lee, V.W.K. \& Rennie, G.C. (1972) A generalised computer program for the treatment of data from competitive protein binding assays including radioimmunoassays. $J$. Lab. clin. Med. 80, 302312 .

Cahill, L.P. (1979) Studies of folliculogenesis in the sheep. These de Doctoráte d'Etat des sciences Naturales, L'Université Paris VI.

Carson, R.S., Findlay, J.K., Burger, H.G. \& Trounson, A.O. (1979) Gonadotropin receptors of the ovine ovarian follicle during follicular growth and atresia. Biol. Reprod. 21, 75-87.

Carson, R.S., Findlay, J.K., Clarke, I.J. \& Burger, H.G. (1981) Estradiol, testosterone and androstenedione in ovine follicular fluid during growth and atresia of ovarian follicles. Biol. Reprod. 24, 105-113.

Driancourt, M.A. Cahill, L.P. (1984) Preovulatory follicular events in sheep. J. Reprod. Fert. 71, 205211.

Driancourt, M.A., Mariana, J.C. \& Palmer, E. (1981) A rapid technique for the histological examination of large ovarian follicles. Reprod. Nutr. Develop. 21, $371-375$.

Hay, M.F. Moor, R.M. (1975) Functional and structural relationships in the Graafian follicle population of the sheep ovary. J. Reprod. Fert. 45, 583-593.

Hay, M.F. \& Moor, R.M. (1978) Changes in the Graafian follicle population during the follicular phase of the oestrous cycle. In Control of Ovulation, Ch. 11, pp. 177-196. Eds D. B. Crighton, G. R. Foxcroft, N. B. Haynes \& G. E. Lamming. Butterworth, London.

Hay, M.F., Cran, D.G. \& Moor, R.M. (1976) Structural changes occurring during atresia in sheep ovarian follicles. Cell Tiss. Res. 169, 515-529.

Hay, M.F., Moor, R.M., Cran, D.G. \& Dott, H.M. (1979) Regeneration of atretic sheep ovarian follicles in vitro. J. Reprod. Fert. 55, 195-207.

Hillier, S.G., Reichert, L.E., Jr \& van Hall, E.V. (1981) Control of preovulatory follicular estrogen biosynthesis in the human ovary. J. clin. Endocr. Metab. 52, $847-856$.

Koering, M.J., Goodman, A.L., Williams, R.F. \& Hodgen, G.D. (1982) Granulosa cell pyknosis in the dominant follicle of monkeys. Fert. Steril. 37, 837-844.

Kruip, Th.A.M. \& Dieleman, S.J. (1982) Macroscopic classification of bovine follicles and its validation by micromorphological and steroid biochemical procedures. Reprod. Nutr. Develop. 22, 465-473.

McNatty, K.P. (1981) Hormonal correlates of follicular development in the human ovary. Aust. J. Biol. Sci. 34, 249-268.

McNatty, K.P. (1982) Ovarian follicular development from the onset of luteal regression in humans and sheep. In Follicular Maturation and Ovulation, pp. 118. Eds R. Rolland, E. V. van Hall, S. G. Hillier, K. P. McNatty \& J. Schoemaker. Excerpta Medica, Amsterdam.

McNatty, K.P., Moore-Smith, D., Makris, A., Osathanondh, R. \& Ryan, K.J. (1979) The microenvironment of the human follicle: interrelationships among the steroid levels in antral fluid the population of granulosa cells and the status of the oocyte in vivo and in vitro. J. clin. Endocr. Metab. 49, 851-860.

McNatty, K.P., Hudson, N.L., Henderson, K.M., Lun, S., Heath, D.A., Gibb, M., Ball, K., McDiarmid, J.M. \& Thurley, D.C. (1984) Changes in gonadotrophin secretion and ovarian antral follicular activity in seasonally breeding sheep throughout the year. $J$. Reprod. Fert. 70, 309-321.

Moor, R.M. (1977) Sites of steroid production in ovine Graafian follicles in culture. J. Endocr. 73, 143-150.

Moor, R.M., Hay, M.F., Dott, H.M. \& Cran, D.G. (1978) Macroscopic identification and steroidogenic function of atretic follicles in sheep. J. Endocr. 77, 309318.

Richards, J.S. \& Kersey, K.A. (1979) Changes in theca and granulosa cell function in antral follicles developing during pregnancy in the rat: gonadotropin receptors, cyclic AMP and estradiol-17 $\beta$. Biol. Reprod. 21, 1185-1201.

Richards, J.S., Ireland, J.J., Rao, M.C., Bernath, G.A., Midgley, A.R., Jr \& Reichert, L.E., Jr (1976) Ovarian follicular development in the rat: hormone receptor regulation by estradiol, FSH, and LH. Endocrinology 99, 1562-1570.

Sokal, R.R. \& Rohlf, F.J. (1981) Biometry: The Principles and Practice of Statistics in Biological Research, 2nd edn. W.H. Freeman \& Company, San Francisco.

Tsonis, C.G. \& Findlay, J.K. (1981) Aromatase activity, steroid content and atresia in ovine follicles. Proc. Endocr. Soc. Aust. 24, Abstr. 75.

Tsonis, C.G., Cahill, L.P., Carson, R.S. \& Findlay, J.K. (1984) Identification at the onset of luteolysis of follicles capable of ovulation in the ewe. J. Reprod. Fert. 70, 609-614.

Weiss, T.J., Seamark, R.F., McIntosh, J.E.A. \& Moor, R.M. (1976) Cyclic AMP in sheep ovarian follicles: site of production and response to gonadotrophins. $J$. Reprod. Fert. 46, 347-353.

Received 20 January 1984 